\title{
IDE Gene
}

National Cancer Institute

\section{Source}

National Cancer Institute. IDE Gene. NCI Thesaurus. Code C112876.

This gene is involved in the catabolism of insulin and other bioactive peptides. 